\title{
AClR
}

Selected Papers of \#AoIR2020:

The $21^{\text {st }}$ Annual Conference of the

Association of Internet Researchers

Virtual Event / 27-31 October 2020

\section{NOSTALGIA FOR THE NEW: VIDEO GAME "REMAKES" AND THE LIMITS OF REFLECTION}

Indira Neill Hoch

Concordia College, Moorhead Minnesota

Introduction: Nostalgia, Retrogaming, and Remakes Nostalgia

In this paper I consider comments posted on the official trailers of Final Fantasy VII Remake and Yakuza Kiwami (from the verified Playstation YouTube channel) as iterations of nostalgia within the context of fifth- and sixth-generation digital game "remakes," where the narrative and characters (Mäyrä's (2008) "shell") of the original game have been retained, but the game's engine and mechanics (Mäyrä's "core") have been wholly replaced with modern technology. Using these comments, I attempt to place responses to these games into Garda's (2013) nostalgia continuum as a way of testing the possibilities and limitations of "nostalgia" as a framework for understanding AAA remakes.

Nostalgia is a predominant framework through which scholars explicate retro-games (Payne, 2008; Suominen, 2008), "neo"-retro game development (Garda, 2013; Sloan, 2016), and retrogamers' community practice (Heineman, 2014; Payne, 2008; Swalwell, 2007). Most retrogaming nostalgia literature follows Jamison (1991) in that reconstructions of the past are oriented towards understanding the present and are consistently linked to commodification.

Considering the origin of digital gaming is traditionally placed in the 1970s, we now share almost fifty years of gaming as part of our digitally mediated lives. While "retrogaming" as a nomenclature still invokes the foundational years of arcade cabinets and the earliest consumer electronics iterations, it increasingly also includes hardware and software from the 8- and 16-bit eras (Garda, 2013; Payne, 2008; Wulf et al., 2018). Scholars have attended to the linkages between "old" video games and nostalgia since the mid-2000s. It follows, then, that fifteen additional years of games should be included in what is considered "old."

Suggested Citation (APA): Neill Hoch, I. (2020, October). Nostalgia for the New: Video Game "Remakes" and the Limits of Reflection. Paper presented at AolR 2020: The $21^{\text {th }}$ Annual Conference of the Association of Internet Researchers. Virtual Event: AolR. Retrieved from http://spir.aoir.org. 
The fifth-generation 32- and 64-bit consoles (Sony Playstation and Nintendo 64, among others) came to market starting in 1993 and most scholarship on gaming and nostalgia has not yet attended to fifth-generation and later titles in a substantial way. Though, there has been work on how contemporary games invoke nostalgia for the historical and aesthetic past in a manner deeply influenced by the "authenticity" of film depictions (Cruz, 2007; Hodson, 2010; Sloan, 2015).

Yet, AAA game publishers have begun to mine this era for titles and profit. Perhaps most anticipated, the Final Fantasy VII Remake from Square Enix was released in April 2020. At least, the first part was released. Square Enix has yet to confirm how many games players will have to purchase in order to complete FFVII Remake. We do know that players will need to purchase multiple \$70 USD (or more) disks in order to complete the game.

Less high profile, in 2016 (Japan, worldwide in 2017) developer Ryu Ga Gotoku Studio released Yakuza Kiwami, a remake of the 2005 title Yakuza. Rather than remaster the game (which was later done for PS3 titles Yakuza 3, 4 and 5), the studio instead opted to remake Yakuza in the eighth-generation engine used for Yakuza 0 and Yakuza 6. Rather than preserve the original game engine and mechanics, the decision was made to modernize both. While the in-game world maintained mid-2000s cultural references, social expectations, and fashions, the game itself was firmly brought into the late-2010s.

Unlike FFVII, Yakuza titles did not experience wide success outside of Japan upon initial launch. The first game's North American release was marred by a trailer with poor quality voice acting that resulted in future titles in the series only being released with subtitles overseas (Constantine, 2010). These differences in reception make for a compelling comparison.

\section{Expressions and Expectations of Restorative and Reflective Nostalgia}

Garda (2013) drawing particularly from the work of Boym (2001) stresses the difference between restorative and reflective nostalgia. Garda constructs a nostalgia continuum ranging from restorative "classic" games to reflective "neo" games that, rather than trying to restore perfectly the conventions and expectations of the classic games, instead look back upon "1980's-ness, 8-bitness and 16-bitness (p. 11)." Neo-games or "playable game criticism" (Sloan, 2016), are a pastiche of an era, rather than an attempt at reproduction. The neo-game designer's nostalgia is one that fosters "creativity and artistic erudition (Garda, 2013, p. 10)." But the remade game does not fit neatly into this nostalgia continuum.

While a YouTube comment for FFVII Remake exclaims "I skipped school in 1997 for the launch and I'm skipping work in 2020 for launch" implies an enduring emotional connection to the title, such nostalgia is not uncomplicatedly placed, as FFVII Remake is not restorative. It's simply not the same game as the original, most notably the battle system has been replaced in its entirety. Comments on the Yakuza trailer at times express giddy excitement for earlier titles becoming playable on modern consoles, while openly admitting that they did not begin playing the series until the release of Yakuza 0 in 2017. Suominen (2008) notes that with some frequency the most avid players of 
retro-styled titles and even retro-rereleases are children who never experienced these games the first time around. But Yakuza's comparatively short timeframe between initial release and remake, as well as its overall violent content, pins a different market: adults who overlooked the game ten years ago and are now experiencing an entire fifteenyear-long series in three years (between 0's initial launch in 2017 to the release of Yakuza 3, 4, and 5 remastered in 2020, seven Yakuza games in total have been released or re-released for the NA market). This relationship between generating a sort of "instant" nostalgia and selling multiple units to the same consumer in a short time frame appears vital.

Testing Garda's continuum by considering remade AAA games and their nostalgic responses in a comparative fashion pushes the adaptability and applicability of the model for incorporating more recent video game content that nonetheless plays on fond feelings for the past. Our lives with digital gaming will only have a deeper history to draw from in the coming years. And, given the profitability of and depoliticization that often accompanies manufactured nostalgia (Hobson, 2010), understanding the limits and possibilities of nostalgia as an analytical framework remains important as more games may take up the mantle of "retro."

\section{References}

Boym, S. The future of nostalgia. Basic Books: New York.

Constantine, J. (2010, March 26). Tokyo beat down: The story of Yakuza. 1Up.com. Retrieved from https://web.archive.org/web/20160525140414/http://www.1up.com/features/storyyakuza-franchise

Cruz, T. (2007). It's almost too intense: Nostalgia and authenticity in Call of Duty 2. Loading: The Journal of Canadian Game Studies, 1.

Garda, M. B. (2013, August). Nostalgia in retro game design. In DiGRA Conference.

Heineman, D. S. (2014). Public memory and gamer identity: Retrogaming as nostalgia. Journal of Games Criticism, 1(1), 1-24.

Hodson, J. (2010). When I'm sixty-four: Beatles Rock Band and the commodification of nostalgia. Loading..., 6(10).

Jameson, F. (1991). Postmodernism: Or, the cultural logic of late capitalism. Durham, NC: Duke University Press.

Mäyrä, F. (2008). An introduction to game studies. London: Sage.

Payne, M. T. (2008) Playing the deja-new: "Plug in and play TV games" and the cultural politics of classic gaming. In Z. Whalen \& L. N. Taylor, Playing the past: History and nostalgia in video games (pp. 51-68). Vanderbilt University Press: Nashville. 
Sloan, R. J. (2015). Videogames as remediated memories: Commodified nostalgia and hyperreality in Far Cry 3: Blood Dragon and Gone Home. Games and Culture, 10(6), 525-550.

Sloan, R. (2016). Nostalgia videogames as playable game criticism. G|A|M|E Games as Art, Media, Entertainment, 1(5).

Suominen, J. (2008). The past as the future? Nostalgia and retrogaming in digital culture. In Proceedings of perthDAC2007. The 7th International Digital Arts and Cultures Conference. The Future of Digital Media Culture (Vol. 15, p. 18).

Swalwell, M. (2007). The remembering and the forgetting of early digital games: From novelty to detritus and back again. Journal of Visual Culture, 6(2), 255-273.

Wulf, T., Bowman, N. D., Rieger, D., Velez, J. A., \& Breuer, J. (2018). Video games as time machines: Video game nostalgia and the success of retro gaming. Media and Communication, (2), 60-68. 